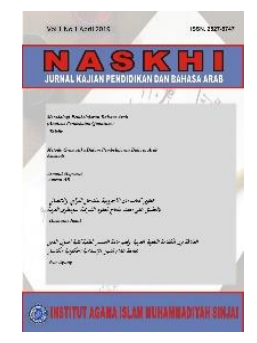

\title{
NASKHI
}

Jurnal Kajian Pendidikan dan Bahasa Arab

Volume 3, No. 1, 2021

ISSN (print) : 2527-5747

ISSN (online) : 2716-3369

Homepage : https://journal.iaimsinjai.ac.id/index.php/naskhi

\section{EVALUASI PEMBELAJARAN BAHASA ARAB BERBASIS MEDIA E-LEARNING}

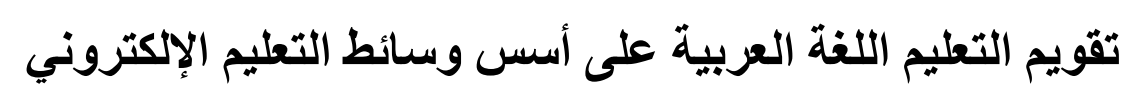

\author{
Muhimmatul Choiroh \\ Mahasiswi Pascasarjana Program Studi Pendidikan Bahasa Arab \\ Universitas Islam Negeri Sunan Ampel Surabaya \\ Email: muhim.hime@gmail.com
}

\begin{abstract}
Learning is inseparable from an evaluation. Along with the development of the times and along with the sophistication of existing technology, various kinds of media are used for evaluation applications. E-learning is the answer to the problems that exist today, where learning methods that use technology are currently needed because the community is currently in the Covid-19 pandemic, so it requires learning to be done remotely. This study uses an evaluative method with a qualitative approach. The aim is to know the advantages and disadvantages of applying google form media. The results are to describe the various media relevant to the evaluation of Arabic learning, as well as to explain the advantages and disadvantages of e-learning based evaluation media, especially google form media. It is hoped that this article can be an alternative choice in evaluating learning, especially Arabic.
\end{abstract}

Keywords: E-Learning, Evaluation of Arabic Learning, Evaluation Media.

\begin{abstract}
Abstrak
Pembelajaran tidak akan terlepas dari sebuah evaluasi, seiring berkembangnya zaman, dan seiring dengan kecanggihan sebuah teknologi yang ada, memunculkan berbagai macam media dalam pengaplikasian evaluasi. E-learning menjadi jawaban atas segala kecanggihan yang ada saat ini, dimana metode pembelajaran dengan menggunakan teknologi saat ini sangat diperlukan karena masyarakat sedang berada dalam masa pandemi Covid-19 yang mana pembelajaran dilakukan jarak jauh. Penelitian ini menggunakan metode Evaluatif dengan pendekatan kualitatif. Dengan tujuan untuk mengetahui kelebihan dan kekurangan media google form dalam pengaplikasiannya. Adapun hasilnya yakni untuk memaparkan macam-macam media yang relevan untuk evaluasi pembelajaran bahasa Arab, juga memaparkan kelebihan dan kekurangan media evaluasi berbasis e-learning, khususnya media google form. Diharapkan dengan adanya artikel ini dapat menjadi pilihan alternatif dalam melakukan evaluasi pembelajaran, khususnya bahasa Arab.
\end{abstract}

Kata Kunci: E-Learning, Evaluasi Pembelajaran Bahasa Arab, Media Evaluasi. 


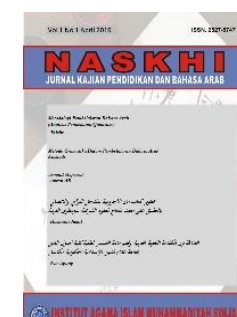

NASKHI

Jurnal Kajian Pendidikan dan Bahasa Arab

Volume 3, No. 1, 2021

ISSN (print) : 2527-5747

ISSN (online) : 2716-3369

Homepage : https://journal.iaimsinjai.ac.id/index.php/naskhi

\section{Pendahuluan}

Upaya pelaksanaan pendidikan formal memberi kesempatan bagi para peserta didik untuk melakukan kegiatan belajar. Melalui proses tersebut, pertumbuhan dan perkembangan peserta didik diharapkan mampu mencapai tujuan yang diharapkan (Ridho, 2018). Dibutuhkan adanya evaluasi dalam pembelajaran karena hal itu sangat penting untuk menentukan keberhasilan siswa, mengabaikan hal tersebut secara tidak langsung juga akan mengabaikan hasil yang akan dicapai peserta didik sesuai norma yang berlaku dalam pendidikan (Ramadhani, 2019). Dari situ hanya akan terlihat bagaimana peserta didik dapat lulus tanpa adanya pertimbangan dan proses dalam hal evaluasi yang baik dan terstruktur.

Evaluasi pembelajaran memiliki tujuan yang tidak akan terpisahkan dari dua hal yakni, guru dan peserta didik. Bagi pendidik, untuk mempertimbangkan kemampuannya dalam pembelajaran dengan memikirkan sejauh mana pembelajaran yang diberikan sesuai dengan tujuan dari lembaga tersebut, kesesuaian metode, strategi, kesesuaian materi yang diajarkan. Bagi siswa evaluasi dilakukan untuk memberikan pengetahuan kepada guru mengenai kekurangan dan kelemahan yang dialami siswa dalam proses pembelajaran dan materi apa yang belum dipahami (Ramadhani, 2019).

Kegagalan peserta didik dalam capaian pembelajaran pun tidak sepenuhnya disalahkan kepada guru mengingat kemajuan teknologi yang semakin pesat menuntut guru agar menjadi lebih kreatif dan inovatif dalam pemanfaatan tersebut, agar mempermudah dalam proses evaluasi pembelajaran. Pada kondisi saat ini yang mana mengharuskan guru untuk memanfaatkan teknologi yang ada, seperti media online yang banyak digunakan seperti Google Classroom, Google Meet, Zoom, Quizziz dan masih banyak lagi media e-learning yang dengan mudah dapat diakses secara gratis melalui komputer maupun gadget yang berbasis android dan IOS.

Sejalan dengan itu kajian mengenai evaluasi pembelajaran bahasa Arab menuai banyak atensi dari para peneliti. Seperti penelitian yang dilakukan oleh Nur Asiah (2015) dalam artikelnya yang menjelaskan tentang evaluasi pelaksanaan pembelajaran E-learning di SMA, adapun hasil dari penelitian tersebut menyebutkan implementasi dan kendala yang dialami saat penggunaan media tersebut. Artikel selanjutnya yang ditulis oleh Wijoyo (2016) tentang pengembangan media pembelajaran E-Learning berbasis aplikasi Lectora Inspire. Adapun hasil dari penelitian ini bahwa analisis kebutuhan menunjukkan guru dan siswa menghendaki sebuah media E-Learning.

Dari penelitian tersebut, sejauh ini belum ditemukan kajian tentang evaluasi pembelajaran bahasa Arab berbasis media E-Learning yang membahas tentang kelebihan dan kekurangan dalam penggunaan salah satu aplikasinya dalam hal ini Google Form. Hal ini perlu dilakukan mengingat kajian ini memiliki beberapa kelebihan. antara lain yakni; Pertama, Meningkatkan kekreatifitasan guru dalam mengajar peserta didik khususnya dalam pelajaran bahasa Arab. Kedua, Dengan adanya pembelajaran jarak jauh ini dapat meminimalisir penyebaran Covid-19. Ketiga, Dengan adanya kajian ini dapat mengikuti perkembangan zaman sekarang.

Media Google Form menjadi objek kajian dalam penelitian ini, dikarenakan media tersebut sangat populer dikalangan guru dan murid pada saat ini, selain penggunaan yang sangat mudah diakses juga memiliki beberapa fitur yang memadai untuk melangsungkan pembelajaran jarak jauh selain itu juga media google form memiliki banyak tema dapat pengaplikasiannya sehingga tidak akan bosan jika menggunakan media tersebut. Kajian ini difokuskan untuk melihat apa saja kelebihan dan kekurangan media google form tersebut. Dengan tujuan untuk mengetahui kelebihan dan kekurangan media google form dalam pengaplikasiannya. Untuk itu penulis tertarik untuk mengkaji tentang ruang lingkup evaluasi pembelajaran bahasa Arab dengan menggunakan media berbasis online.

\section{Metode}

Penelitian ini merupakan penelitian evaluatif dengan pendekatan kualitatif. Menggunakan Jenis penelitian ini karena mengkaji dan menilai keberhasilan, manfaat, kegunaan, sumbangan dan kelayakan suatu program, produk atau kegiatan suatu lembaga dengan kriteria tertentu. Adapun teknik pengumpulan data pada penelitian ini berupa studi dokumentasi yang mana untuk mempelajari dan menganalisis bahan-bahan tertulis.digunakan untuk menggali data tentang evaluasi penggunaan media 


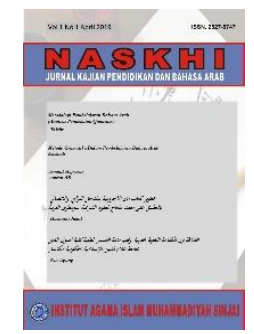

\section{NASKHI}

\section{Jurnal Kajian Pendidikan dan Bahasa Arab \\ Volume 3, No. 1, 2021}

ISSN (print) : 2527-5747

ISSN (online) : 2716-3369

Homepage : https://journal.iaimsinjai.ac.id/index.php/naskhi

E-Learning dalam pembelajaran bahasa Arab. Sumber dokumentasi berupa media E-Learning dalam pembelajaran jarak jauh menggunakan teknologi (Hariwijaya, 2007).

Dalam penelitian ini terdapat empat prosedur yang akan dilakukan; Pertama; persiapan pengumpulan data diawali dengan tahapan menentukan tema, dimana penulis mencari masalah yang akan diangkat menjadi sebuah penelitian dengan cara menelaah dari beberapa karya ilmiah yang telah ditulis sebelumnya. Kedua; pelaksanaan pengumpulan data dengan menelaah objek yang akan dikaji. Ketiga; pengolahan data dengan metode dan teori yang telah ditentukan setelah menganalisis objek berupa media E-Learning, dan yang Keempat; penyusunan hasil analisis, diharapkan melalui penelitian ini dapat mengembangkan program yang belum terlaksana dengan baik.

\section{Hasil dan Pembahasan}

\subsection{Evaluasi Pembelajaran Bahasa Arab}

Kata Evaluasi berasal dari bahasa Inggris "Evaluation"; dalam bahasa Arab "al-Taqdir" yang artinya penilaian. Akar katanya adalah value, dalam bahasa Arab: al-Qimah; dalam bahasa Indonesia berarti nilai. Demikian secara harfiah, evaluasi pendidikan (educational evaluation / al-Taqdir alTarbawiy) dapat diartikan sebagai penilaian dalam bidang pendidikan atau penilaian tekait kegiatan pendidikan. Lingkup evaluasi lebih luas lagi daripada penilaian, sedangkan penilaian terfokus pada aspek tertentu saja dari bagian ruang lingkup tersebut. Evaluasi dan penilaian bersifat kualitatif sedangkan pengukuran bersifat kuantitatif yang diperoleh hasilnya dengan pengujian suatu alat ukur atau instrumen (Miladya, 2016).

Evaluasi belajar dan pembelajaran merupakan sebuah proses untuk menentukan nilai pembelajaran yang dilaksanakan, melalui kegiatan penilaian dan pengukuran belajar dan pembelajaran. Pengukuran dan pembelajaran merupakan proses membandingkan tingkat keberhasilan belajar yang ditentukan secara kuantitatif, sedangkan penilaian belajar dan pembelajaran adalah proses pembuatan keputusan nilai keberhasilan belajar secara kualitatif.

Menurut Supriyadi, (2011) lembaga Administrasi Negara (LAN) mengemukakan batasan definisi mengenai Evaluasi Pendidikan sebagai Berikut:

1. Sebagai proses atau kegiatan untuk menentukan kemajuan pendidikan, dibandingkan dengan tujuan yang ditentukan.

2. Sebagai usaha memperoleh informasi berupa Feed back bagi penyempurna pendidikan.

\section{Bagan Evaluasi Pendidikan}

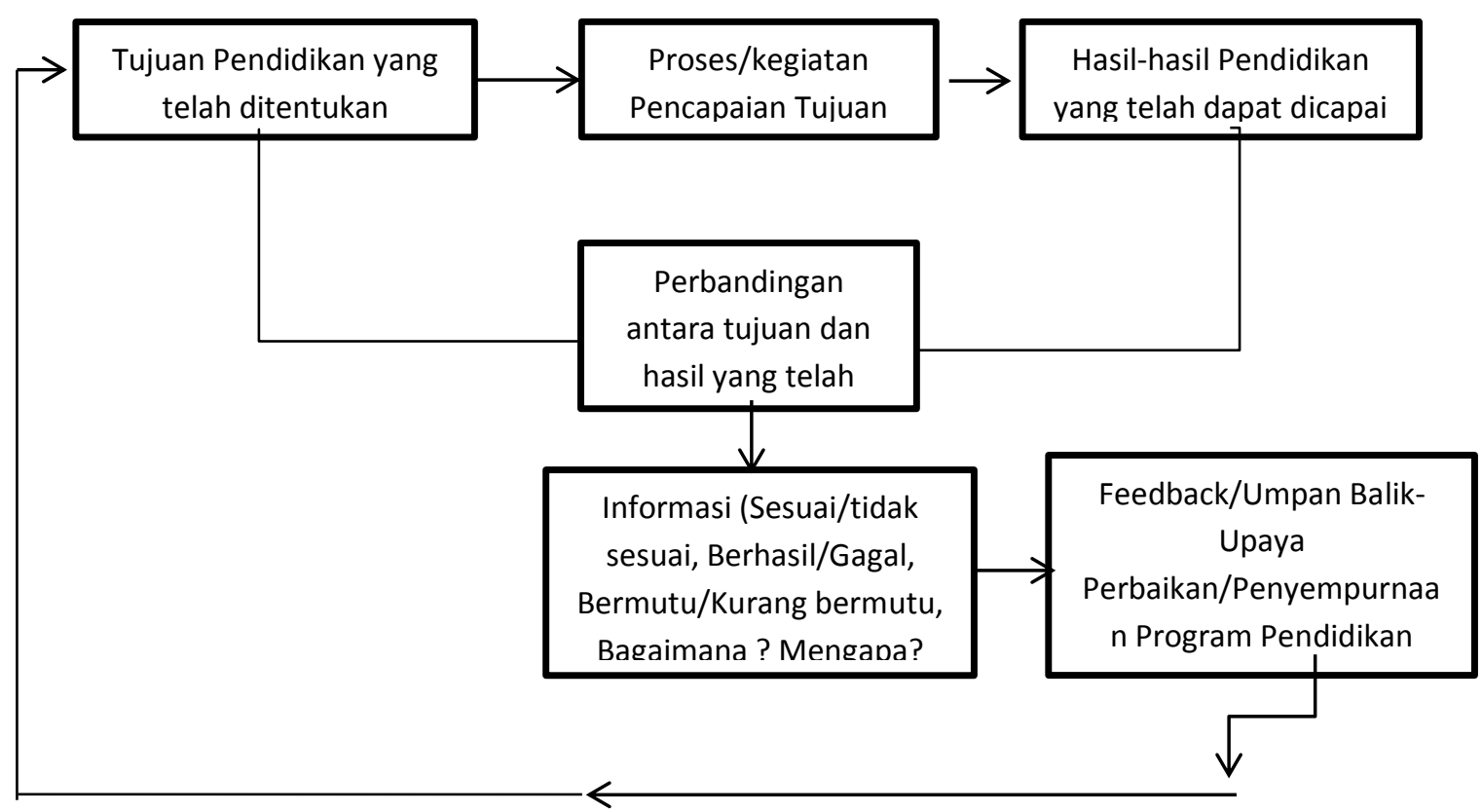

Sumber: Supriyadi, (2011) 


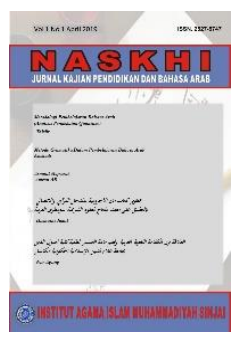

\section{NASKHI}

\section{Jurnal Kajian Pendidikan dan Bahasa Arab \\ Volume 3, No. 1, 2021}

ISSN (print) : 2527-5747

ISSN (online) : 2716-3369

Homepage : https://journal.iaimsinjai.ac.id/index.php/naskhi

Bagan diatas dapat dipahami bahwa dalam kegiatan evaluasi pendidikan langkah awal yang perlu ditentukan adalah tujuan pendidikan, dalam hal ini adalah tujuan intruksional dan untuk mencapai tujuan tersebut dilaksanakan kegiatan pendidikan berupa proses belajar mengajar. Untuk mengetahui berhasil tidaknya proses pembelajaran diadakan suatu penilaian yang nantinya hasil akan dibandingkan dengan tujuan yang telah ditentukan setelah itu baru diketahui berhasil atau tidaknya, sesuai atau tidaknya antara hasil dan tujuan. Dari hasil atau informasi itulah yang nantinya akan dijadikan bahan perbaikan dan penyempurnaan program pendidikan.

Pembelajaran merupakan sebuah program, dapat pula diartikan sebagai proses, cara, perbuatan yang menjadikan orang atau makhluk hidup belajar. Membutuhkan sebuah rancangan perencanaan yang melibatkan banyak pihak dalam pengaplikasiannya, baik dari guru maupun peserta didik. Karena keduanya merupakan bagian dari komponen dalam pembelajaran, mempunyai peran dan keterlibatan untuk mencapai sebuah tujuan pembelajaran, berupa kompetensi dalam bidang studi yang menghasilkan output pembelajaran. Program pembelajaran yang dibuat oleh guru tidak selamanya dapat dilaksanakan dengan baik dan efektif. Maka dari itu program pembelajaran yang memiliki kelemahan setelah pengaplikasiannya tidak terjadi lagi pada program pembelajaran yang akan datang, perlu diadakan evaluasi, tidak hanya pada bidang studi umum dan agama saja tetapi juga bidang studi kebahasaan perlu dilakukan evaluasi. Karena bahasa memiliki beberapa fungsi diantaranya; Ekspresif, Fatis, Kognitif, Komunikatif.

Bahasa Arab sebagai salah satu bahasa yang mempunyai fungsi-fungsi yang disebutkan diatas. Maka fungsi pembelajaran bahasa Arab dapat diartikan sebagai suatu proses memfungsikan bahasa Arab kepada peserta didik atau pembelajar bahasa Arab baik dalam ranah kebahasaan, kependidikan, sosial, keagamaan, dan kenegaraan (Iswanto, 2017).

Evaluasi pada program pembelajaran bahasa Arab merupakan suatu rangkaian kegiatan yang dilaksanakan dengan menggunakan landasan teori yang tepat diikuti perencanaan dan tahapan yang sistematis. Bertujuan untuk melihat tingkat keberhasilan pembelajaran bahasa Arab. Selain itu juga berguna untuk melihat apakah program pembelajaran bahasa Arab sesuai dengan kebutuhan keadaan kelas atau sebaliknya, Jika sesuai maka program pembelajaran tersebut dapat dilanjutkan, namun apabila belum mencapai kesesuaian dan belum efektif maka perlu diadakan pembaharuan ulang (Setyawan, 2018).

\subsection{Selayang Pandang Media E-Learning}

E-Learning atau yang biasa disebut dengan pembelajaran berbasis elektronik/jaringan merupakan pembelajaran menggunakan sistem elektronik untuk mentransfer kemampuan dan pengetahuan, metode pembelajaran ini sebagai salah satu pembelajaran yang memanfaatkan kecanggihan teknologi dalam mencapai keefektivitasan dalam sebuah pembelajaran. Dengan $E$ Learning pembelajaran dapat diselenggrakan dengan jumlah peserta yang tidak terbatas dan dengan jangkauan yang sangat luas. Awal mula munculnya pembelajaran berbasis media E-Learning ini di Negara Amerika dan Kanada dengan bermunculan banyaknya situs E-Learning yang Open Access yang dibagikan berupa tautan dapat diakses semua orang dan kalangan. Sedangkan dalam prakteknya di Indonesia masih sangat terbatas penggunaannya, efektivitas pembelajaran berbasis E-Learning muncul sejak adanya masa darurat Coronavirus Disease (Covid-19).

E-Learning dibentuk dari beberapa komponen yakni (1) Sistem dan Aplikasi E-Learning biasa disebut dengan Learning Management System (LMS) sistem perangkat lunak yang memvirtualisasikan proses belajar mengajar konvensional untuk dokumentasi, administrasi, ruangan kelas dan peristiwa online. (2) Infrastruktur E-Learning peralatan yang digunakan dalam proses belajar berupa Personal Computer (PC), jaringan komputer, internet dan perlengkapan multimedia lainnya. (3) Konten E-Learning yakni berupa bahan ajar yang ada pada proses pembelajaran $E$ Learning (Hartanto, 2016).

\subsection{Media E-Learning dalam Pembelajaran Bahasa Arab}

Revolusi teknologi dan industri 4.0 memunculkan kemudahan yang dapat membantu manusia dalam hal peningkatan kinerja teknologi salah satunya dalam pembelajaran jarak jauh yang biasa 


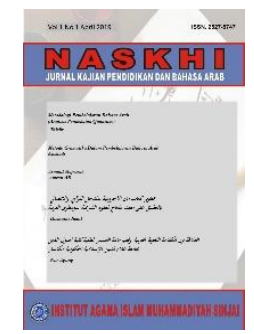

\section{NASKHI}

\section{Jurnal Kajian Pendidikan dan Bahasa Arab \\ Volume 3, No. 1, 2021}

ISSN (print) : 2527-5747

ISSN (online) : 2716-3369

Homepage : https://journal.iaimsinjai.ac.id/index.php/naskhi

disebut dengan E-Learning atau pembelajaran dalam jaringan (Daring). Yang mana proses dalam pembelajaran tersebut menggunakan bantuan elektronik dalam mewujudkan efektivitas pembelajaran. Namun, pembelajaran jarak jauh tidak berkembang secara maksimal. Pembelajaran ini merupakan salah satu metode program belajar dari rumah. Media evaluasi E-Learning mempunyai banyak macam yakni; dalam hal tatap muka; Zoom merupakan aplikasi teleconference yang dapat menggabungkan konferensi video, pertemuan online, obrolan hingga kolaborasi seluler, dapat digunakan sebagai media komunikasi, digunakan juga dalam proses belajar mengajar jarak jauh dari tingkatan sekolah dasar hingga Perguruan tinggi. Kemudian aplikasi Google Meet yakni layanan komunikasi video yang dikembangkan oleh google. Pemberian evaluasi berupa kuis dapat menggunakan aplikasi Quizizz digunakan untuk membuat formulir yang dijadikan sebagai kuis dalam evaluasi pembelajaran. Media lainnya yakni Kahoot merupakan software untuk pembelajaran online berbasis permainan yang menjadikan pembelajaran lebih optimal dan menyenangkan. Kemudian dalam hal pemberian soal evaluasi yang masif digunakan pada saait ini yaitu; Google Classroom merupakan layanan berbasis web yang dapat diakses secara gratis, dikembangkan oleh google ditujukan untuk kegiatan sekolah jarak jauh, pemberian tugas tanpa harus bertatap muka, kemudian media Google Form digunakan untuk membuat, mengedit dan menyimpan dokumen. Keseluruhan media dapat diakses dengan mudah dan tanpa berbayar. Untuk mengakses media yang dikembangkan oleh Google diharuskan bagi penggunannya untuk memiliki akun. Karena fitur tersebut layanannya tergabung atau terintegrasi dengan akun Google, cara pembuatannya cukup mudah hanya dengan mengunduh Google Mail di aplikasi Play Store, tetapi jika pengguna memiliki ponsel berbasis Android sudah dipastikan didalamnya memiliki Aplikasi Google Mail/Gmail kemudian tinggal mendaftar untuk memiliki akun Google.

Media evaluasi yang sangat populer dikalangan Guru dan Siswa dari tingkatan Sekolah Dasar hingga Perguruan Tinggi ini adalah Google Form yang merupakan salah satu dari beberapa bagian dari fitur-fitur google yang dapat diakses melalui brwoser secara gratis, fitur ini dapat mengumpulkan informasi dari banyak responden untuk berbagai kebutuhan. Fungsi dari fitur ini untuk membuat formulir survei pelanggan, registrasi online, kuis, formulir RSVP event, formulir lamaran kerja hingga pembuatan soal untuk evaluasi pembelajaran. Dengan menggunakan google form tak perlu khawatir akan kesulitan dalam menggunakannya karena memiliki interface yang sangat mudah digunakan dimana kita dapat menambahkan, mengurangi maupun mengubah setiap komponen yang ada di formulir hanya dengan melakukan drag and drop, untuk memperindah tampilan dalam fitur tersebut dapat menggunakan pilihan palet warna dan mengganti tema sesuai keinginan. Informasi yang masuk melalui Google Form secara otomatis akan tersimpan di spreadsheet, selain menyimpan, data yang terdapat disitu dapat diedit sebelum diolah lebih lanjut dan dikirimkan kepada penerima.

Dibalik kemudahan dan kecanggihan teknologi berbasis E-Learning yang ada saat ini memunculkan banyak alternatif dalam pengaplikasian evaluasi pembelajaran, dalam hal ini aplikasi Google Form yang sangat gencar diminati oleh banyak kalangan dari kalangan guru hingga dosen, dari tingkat sekolah dasar hingga perguruan tinggi. Namun hal itu tidak luput dari adanya kekurangan dan kelebihan dalam penggunaanya, antara lain:

Adapun kelebihan dari google form; (1) Efisien, tidak memerlukan waktu dan tempat yang khusus untuk pengerjaannya, akses yang mudah dan mengurangi penggunaan kertas (Paperless), (2) Mudah dalam pembuatan soal dan pengoreksiannya, karena jawaban yang masuk akan dikoreksi secara otomatis oleh Google Form dan hasil siswa dapat dilihat jika pengaturan diatur dengan mode "responden dapat melihat diagram ringkasan dan respon teks", (3) Pendidik dapat mengunduh rekapan hasil evaluasi peserta didik dalam format Microsoft Excel lengkap dengan skor dan jawaban peserta didik, (4) Gratis, dapat mengakses Google Form tanpa mengeluarkan biaya sepeserpun atau tanpa biaya berlangganan, (5) Url dapat diperpendek, aplikasi ini menyediakan pengeditan URL yang semula panjang bisa diperpendek sehingga mudah untuk membagikan link tersebut dan mudah untuk kita mengingat alamat form, (6) Tema yang beragam, dengan banyak tema yang disediakan sehingga pengguna tidak merasa bosan. 


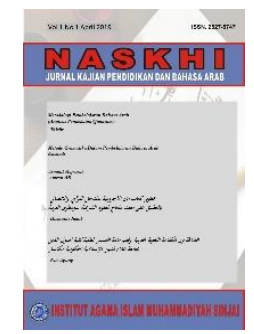

\section{NASKHI}

\section{Jurnal Kajian Pendidikan dan Bahasa Arab \\ Volume 3, No. 1, 2021}

ISSN (print) : 2527-5747

ISSN (online) : 2716-3369

Homepage : https://journal.iaimsinjai.ac.id/index.php/naskhi

Dari banyaknya kelebihan, terdapat pula kekurangan pada aplikasi ini, antara lain; (1) Memerlukan jaringan internet, (2) Tidak terdapat pemberitahuan email, media ini tidak mengirimkan pemberitahuan email ketika responden mengirimkan survei, sehingga kita harus membuka secara manual melalui menu respon yang ada di Google Form, (3) Memiliki pilihan ekspor yang terbatas, yaitu hanya dapat diekspor ke Google Sheets dan pdf, sampai saat ini belum dapat diubah menjadi file word (.docx)

\section{Simpulan}

Interaksi antara pendidik dan peserta didik, antara peserta didik satu dengan yang lainnya yang dilakukan secara maksimal akan menunjang keberhasilan pembelajaran berbasis E-Learning. Kemajuan teknologi informasi dan telekomunikasi yang mudah diakses dan tanpa biaya yang membebani penggunanya dapat menjadikan fasilitas yang memadai untuk berlangsungnya proses pembelajaran pada saat ini yang dilakukan jarak jauh tanpa tatap muka dan tidak membatasi ruang dan waktu, hanya dalam satu genggaman proses pengajaran dapat berlangsung dengan mudah dan efesien. Dengan kemajuan ini pendidik harus lebih kreatif dan inovatif untuk menjadikan pembelajaran menjadi hidup dan terarah. Bagi peserta didik, mereka dengan mudah dapat mengakses materi-materi yang diberikan kapan saja dan dimana saja, dan juga peserta didik dapat memanfaatkan kecanggihan teknologi melalui gadget masing-masing, tidak hanya digunakan untuk bermain game semata, melainkan juga mereka mendapat ilmu dan pengetahuan didalamnya.

Berbagai kecanggihan yang ditawarkan oleh kemajuan jaman saat ini menuntut guru untuk dapat memanfaatkannya, dengan cara melakukan evaluasi kegiatan belajar mengajar secara online, maka digunakanlah media berbasis E-Learning dalam hal ini Google Form untuk merealisasikannya, terdapat banyak kelebihan dari media tersebut diantaranya; Efisien, mudah digunakan, tanpa biaya/gratis, dan memiliki model tema yang beragam. Namun dibalik kelebihan yang ditawarkan, terdapat pula kekurangan dari media tersebut yakni antara lain; memerlukan jaringan yang terkoneksi oleh internet, tidak terdapat pemberitahuan secara otomatis, dan hanya dapat di akses melalui google sheets dan pdf saja.

\section{Daftar Pustaka}

Ramadhani, Dony Ahmad (2019) 'Evaluasi Pengajaran Bahasa Arab Dengan Media Online Di Perguruan Tinggi', Al Mi'yar: Jurnal Ilmiah Pembelajaran Bahasa Arab Dan Kebahasaaraban, $2.1<\mathrm{https}: / /$ doi.org/10.35931/am.v2i1.105>.

Ridho, Ubaid. (2018) 'Evaluasi Dalam Pembelajaran Bahasa Arab', An Nabighoh Jurnal Pendidikan Dan Pembelajaran Bahasa Arab, $20.01 \quad<$ https://doi.org/10.32332/annabighoh.v20i01.1124>.

Asiah, Nur. (2015) Evaluasi Pembelajaran E-Learning di SMA Budaya Bandar Lampung, Jurnal Ilmiah Pendidikan Teknik elektro, Vol. 1 No.2

Wijoyo, Toto. (2016) Pengembangan Media Pembelajaran E-Learning Berbasis Aplikasi Lectora Inspire Untuk Keterampilan Membaca Bahasa Arab Siswa MTs kelas VIII, Journal of Arabic Learning and Teaching 5 (1)

Hariwijaya (2007) Metodologi dan Penulisan Skripsi, Tesis dan Disertasi, (Yogyakarta: Parama Ilmu) 


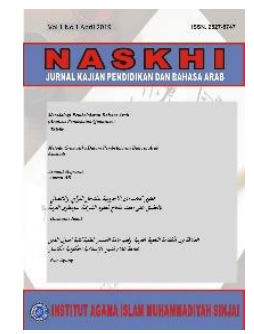

NASKHI

Jurnal Kajian Pendidikan dan Bahasa Arab

Volume 3, No. 1, 2021

ISSN (print) : 2527-5747

ISSN (online) : 2716-3369

Homepage : https://journal.iaimsinjai.ac.id/index.php/naskhi

Miladya, Ramadhani. Evaluasi Dalam Pembelajaran Bahasa Arab, Program Pascasarjana Keguruan Bahasa Arab Universitas Negeri Malang, ISBN: 978-979-495-813-1

Supriyadi, Gito. (2011) ‘Pengantar \& Teknik Evaluasi Pembelajaran’, Book, Malang

Iswanto, Rahmat. (2017) 'Pembelajaran Bahasa Arab Dengan Pemanfaatan Teknologi', Arabiyatuna: Jurnal Bahasa Arab, 1.2, 139 <https://doi.org/10.29240/jba.v1i2.286>.

Setyawan, Cahya Edi. (2015) 'Desain Evaluasi Program Pembelajaran Bahasa Arab', Jurnal Komunikasi Dan Pendidikan Islam, 4.1

Media Evaluasi Pembelajaran, 'Media Pembelajaran Daring Berorientasi Evaluasi'

Hartanto, Wiwin. (2016) 'Penggunaan E-Learning Sebagai Media Pembelajaran', Jurnal Pendidikan Ekonomi, 10.1 